\title{
IS THERE A TRADE-OFF BETWEEN SUPERVISION AND WAGE? EVIDENCE FROM A METAL MECHANICAL FIRM IN SOUTHERN BRAZIL
}

\author{
Reno Schmidt Junior \\ Gibran da Silva Teixeira \\ Felipe Garcia Ribeiro \\ Giácomo Balbinotto Neto
}

\begin{abstract}
Resumo
O objetivo deste trabalho é testar a existência do trade-off entre supervisão e salários em uma empresa do ramo metal mecânico no sul do Brasil. A metodologia utilizada para avaliar os efeitos sobre a produtividade e a eficiência dos trabalhadores foi o estimador de diferenças em diferenças. Avaliando os resultados, constatou-se que o aumento de supervisão gerou um aumento na produtividade entre $13,5 \%$ a $26,8 \%$. Assim, com o aumento da produtividade, cabe à firma escolher entre aumentar o nível de supervisão ao custo de US\$ 624,98 ou praticar salários eficiência ao custo de US\$2.907,72.
\end{abstract}

Palavras-chave: Salários eficiência. Supervisão. Insider Econometrics.

\begin{abstract}
The objective of this work was to test the existence of a trade-off between supervision and wages in a metal mechanical firm in Southern Brazil. The methodology used to assess the effects on productivity and the worker efficiency was the differences-in-differences estimator. Evaluating the results, it was found that with increased supervision, there was an increase in productivity ranging between $13.5 \%$ and $26.8 \%$. Therefore, with increased productivity, the company has to choose between increasing the level of supervision, at a cost of US\$ 624.98 or practicing efficiency wages at a cost of US\$2,907.72.
\end{abstract}

Keywords: Efficiency wages. Supervision. Insider Econometrics.

JEL classification: M51, M52, M54

DOI: http://dx.doi .org/10.11606/1413-8050/ea153858 


\section{Introduction $^{1}$}

The goal of this paper was to test the existence of a trade-off between supervision and wages using the efficiency wages model (Shapiro \& Stiglitz 1984) in a private firm in the metal mechanics field. The basic question to be addressed is what the effects and implications of the different levels of supervision are on the workers performance in a context of asymmetric information. The efficiency wages theory (shirking model) suggests there is a trade-off between supervision and wages. If there is such trade-off, companies would have to choose between two human resource practices: adoption of wages higher than the labor market wage average (efficiency wages), or the increase of supervision to improve the possibility of detecting worker shirking behavior. Since this paper uses data from within a private firm, it also aims to contribute to the modern literature on Personnel Economics which according to Lazear \& Shaw (2007) "(...) drills deeply into the company to study human resource management practices".

The case and empirical analyses are based on data from Bruning, a metal mechanic firm, located in the municipality of Panambi (Rio Grande do Sul Brazil). Bruning has two groups of workers in an assembly line of aluminum fuel tanks for trucks. One group works at daytime shift (group 1) and the other at night shift (group 2). For group 2 there was an increase in the degree of supervision in the assembly line at a given time. The paper considers two hypotheses. First, before the change in supervision for group 2, productivity should be higher in Group 1 than in Group 2 (with different supervision levels and without wage differences). Second, after the change in supervision for group 2, the productivity of Group 2 should be near or similar to that of Group 1 (with the same supervision level). In other words, the goal here is to verify whether the increase in the degree of supervision in the second group had any positive impact on its labor productivity and labor efficiency. To accomplish the task, the empirical strategy relies on differences-in-difference estimation, since data of two different groups in relation to the supervision in two different moments are available: before and after the supervision shock. The paper investigates the supervision shock on both the productivity and efficiency of workers.

This paper follows the approach of Shaw (2009), entitled Insider Econometrics, that seeks to test the impact of human resources policies and other management practices on employee productivity (Personnel Economics). In this paper, are two of the main characteristics of an Insider Econometrics study pointed out by Ichniowski \& Shaw (2013) are present: data from within the firm and an econometric tool to measure the effect of a change in the administrative/managerial practices.

Similar to a large number of Personnel Economics articles, this paper uses personnel data from a single firm. It is possible to organize these kind of Personnel Economics papers into two groups. The first group studies the role of incentives and payment schemes on employee productivity (Lazear 2000, Bandiera et al. 2005, 2007, 2009, Franceschelli et al. 2010), while the second group evaluates the effects of different teamwork arrangements on employee productivity (Bandiera et al. 2009, Jones et al. 2010, Frick et al. 2013). No

\footnotetext{
${ }^{1}$ We would like to thank the Edward Lazear, Helio Zylberstajn, Luiz Alberto Esteves and Daniel Uhr for their comments, as well as the participants of the PPGE/UFRGS seminar and financial support under the CAPES Pró-Integração Project (Announcement 55/2013).
} 
papers were found in Personnel Economics with Insider Econometrics that investigated the role of supervision on productivity. In addition, no papers of Personnel Economics with Insider Econometrics involving Brazilian firms were found. The authors believe that the present study contributes to filling these gaps.

With respect to the use of case studies in Personnel Economics, Jones et al. (2008) argue that econometric case studies (whose definition is similar to Insider Econometrics) may provide better internal validity than studies based on surveys of cross-company, cross-industry, etc. According to those authors, this happens because in case studies it is possible to get better measurements of both dependent variables (producitivity, efficiency, etc) and Human Resources Management (HRM) than in general surveys. Secondly, a case study allows for a personal interaction between researchers and the managers of a firm. Such interaction may result in a better understanding and identification of important mechanisms and channels that link HRM and labor productivity. With regard to the external validity of case studies, Jones et al. (2008) have argued that the criticism that involves them is overstated. These authors claim that statistical generalization is indeed not appropriate when a research relies on case study because probably one single firm does not represent a population of firms. However, analytical generalization, which involves testing hypothesis obtained from theory, may be strengthened due both to the high internal validity of such studies and the adequate use of theory for the specific context which is usually very detailed in case studies. According to Ichniowski \& Shaw (2013), the rich micro-level data on workers, products, management practices, production process, and other firm characteristics allows the test of theories on the determinants of the worker and firm productivity. These last points reinforce the contributions of this paper as it tests theoretical hypothesis in an "experiment" with high internal validity.

On the main findings of this paper, the results obtained from the differencein-difference estimator suggest an increase in average daily productivity of the workers who belong to Group 2 after the supervision increase. The estimated effect is between $13.5 \%$ and $26.8 \%$, depending on the sample. The results are robust to different strategies of falsification. Regarding efficiency, the estimated results are significant in only one of the samples used, which does not allow us to perform a precise analysis of the effect of supervision increase on this variable.

In addition to this introduction, the paper has four more sections. In 2, the shirking model is developed and discussed, with its theoretical implications for the analyzed case. The third section provides a description of the Bruning Industry, and detailing of the case. The fourth section presents the empirical strategy and the analysis of the results. Finally, the fifth section contains the conclusion with the main results of the case study, based upon what is seen in the preceding sections.

\section{Shirking model and supervision level}

In the shirking model, Shapiro \& Stiglitz (1984), the utility function $(U)$ for the worker presents a relationship between wage $(w)$ and effort $(e)$ and seeking to maximize this function, it is assumed that: 


$$
U(w, e) e \quad \frac{\partial U}{\partial w}>0 ; \frac{\partial U}{\partial e}<0
$$

The higher the worker's effort $(e)$, the smaller the utility $(U)$ of the wage $(w)$. In case the worker is unemployed, he will receive an unemployment benefit $(w)$ and the effort will be zero $(e=0)$.

For the unemployed worker, there is a probability $b$, per unit of time, in which he will be out of work, due to replacement (frictional unemployment $\left.\frac{1}{b}\right)$, this rate is assumed to be exogenous. In addition, each employee has an intertemporal discount rate $(r)$ which maximizes the present value of utility $(U)$. It is assumed that this discount rate will always be higher than zero $(r>0)$. The only choice the worker has is to select the effort level. In case the worker performs his work with his usual effort level (chooses working hard, no shirking), he will receive a wage $(w)$ and will keep his job until exogenous factors result in a dismissal.

In case he chooses not to work hard (shirking), there is a possibility $(q)$, per unit of time, of him being caught (by the supervision) and getting laid off.

It is to be expected that the worker will choose the effort level that maximizes his intertemporal utility. This involves a comparison between the values of the utilities, in the cases of working hard (no shirking), working hard (shirking) and when the worker is unemployed. Thus, the expected utility must be calculated, throughout the life cycle of a worker who opts for "shirking" and match the expected utility throughout the life cycle, for a worker who chooses to "shirk". The worker will choose working hard (no shirking), only if the utility of not shirking is higher than the utility on shirking. Thus, this becomes the condition for the worker to choose working hard (no-shirking condition NSC). Calculating the critical wage $(w)$ that respects this condition, we have:

$$
w \geq e+\dot{w}+\left(\frac{e}{q}\right)\left(\frac{b}{u}+r\right)
$$

Where $u=\frac{(N-L)}{N}$ represents the unemployment rate.

According to Stiglitz (2009), when firms manage to select the monitoring level $(q)$ they can then make an exchange (trade-off) between monitoring level and wages. Supposing a variation occurs in the supervision level $(q)$ ceteris paribus, it is possible to build an inverse relation between the supervision level and the wage that attends the NSC condition, an issue that will be assessed in the article.

In the next section an analysis is made of a case of variation in the level of supervision of a firm in the metal mechanic area, testing the main propositions of the shirking model, developed in this section.

\section{Case Study}

The objective of this section is to relate the theory of the efficiency wage (shirking model) to the case of Bruning Tecnometal ${ }^{2}$, using productivity data of the

\footnotetext{
${ }^{2}$ Bruning Tecnometal LTD was founded by Mr. Ernesto Rehn on April 1, 1947, in the city of Panambi in Rio Grande do Sul, where its production plant is located, to this day. Currently, Bruning produces shaped metal parts by means of low temperature processes (room temperature), called metal stamping. Added to this, the firm has welding and painting processes, which are
} 
production line of aluminium made fuel tanks, for a given change in the level of supervision and the resulting implications. For this analysis the case study methodology will be used. This methodology has already been used in similar situations by Raff \& Summers (1987) in the case of Ford, and by Lazear (2000), in the case of Safelite. Besides, for this investigation, a research strategy will be adopted in line with what Bartel et al. (2004) and later Ichniowski \& Shaw (2013) called Insider Econometrics ${ }^{3}$.

One of the advantages of researching with data from within the company, according to Ichniowski \& Shaw (2013), is the possibility of identifying the behavioral mechanisms that explain the connection between the administrative policies and the results, in terms of productivity, before "noises" are incorporated to the data.

Bruning is located in Panambi, a city with 38,058 inhabitants ${ }^{4}$ and has 3,400 workers. It employs $25.40 \%$ of the male population between 19 and 59 years of age and $4.16 \%$ of the female population between 19 and 59 years of age IBGE (2010). Bruning suffers an enormous shortage of manpower. Therefore, there is a constant effort to reduce the total number of employees. The elimination of a supervisor from the production line of aluminum fuel tanks is among this efforts. This elimination lasted from November 2010 to October 2011.

The data of the case refer to primary data obtained from two sources (1) through a monitoring system called $\mathrm{CODI}^{5}$, that supplies the andon ${ }^{6}$ functions of takt time ${ }^{7}$ measurer in the production line of aluminium-made fuel tanks; and (2) through the Human Resources department of the firm. The data were measured for two groups of workers, identified in this study as Group 1 and Group 2.

The following data were collected: (1) Performance (productivity); (2) Efficiency; (3) Availability; (4) Salaries. Where: (1) Performance (productivity: is the relationship between the time spent for the production of the item in question and the theoretical time considered to form the cost of the item. In a simplified manner, it is the speed (effort / concentration) with which the operator works; (2) Efficiency: is the relationship between the time the machine is in production by the total time in which it is available for production. It can be said, in a simplified way, that it is the total amount of time in which the

sometimes necessary to supplement the pieces produced for customers. In 2013, Bruning had a revenue of US\$ 256 million. With such a revenue, Bruning is considered one of the 1,000 largest companies in Brazil (Melhores \& Maiores Exame, 2013). Today, Bruning represents $48 \%$ of the tax revenue of the city of Panambi

${ }^{3}$ Such a case can be classified as Ichniowski \& Shaw (2013) Insider Econometrics, as it meets the five characteristics of Insider Econometric Research, which are: (1) estimate a regression of productivity, where productivity is a function of some administrative practice; (2) identify why administrative practices alter the level of productivity and where they have greater and lesser impact; (3) modeling administrative practices; (4) work with data the company level (microlevel data) related to employees or group of employees with a common production function; and (5) use field research or interviews with managers within companies to formulate testable hypotheses and interpret results, providing additional evidence on the economic mechanisms behind the results.

${ }^{4}$ According to IBGE, data from the 2010 census.

${ }^{5}$ A system manufactured by CODI enterprise (http : / / www . codi .com.br).

${ }^{6} \mathrm{~A}$ visual management tool that shows the state of operations during production. An andon can indicate the production status (amount produced, amount produced with defects, time when machine stopped). For more details see Marchwinski \& Shook (2003).

${ }^{7}$ Time available for production divided between the client's demand. For more details see Marchwinski \& Shook (2003). 
operator is effectively working; (3) Availability: time in which the machine was available for production within the working shifts. It takes into account the total time of the shifts, minus the times for maintenance or unexpected stops $^{8}$; and (4) Wages: nominal net income earned by the workers in each of the functions.

$4.8 \%$ of the employees working in the production of aluminium fuel tanks, responsible for $15 \%$ of the firm revenue. This is produced to meet the needs of truck assemblers operating in Brazil. Within Bruning, there is a separate area (called line 47), isolated from the rest of the factory, built exclusively to hold the production line of the fuel tanks. This line does not suffer interference from other production sites at Bruning.

The CODI controls are installed in the operations of welding of partitions and of lids. Those stages are the robotized welding operations of the fuel tanks and constitute the bottleneck operations ${ }^{9}$ in the production of aluminium fuel tanks. In this way, these two operations dictate the production rhythm of the entire assembly line.

The welding operations, for these two points are done by pre-programmed robots, prepared exclusively for these operations. The operators who work in these two stages receive 40 hours training on soldering and identification of possible defects, and another 40 hours training on the operation of the robot. The times and movements of these two operations are quantified and analyzed by the Bruning production engineering team. Nonetheless, the operator can opt "not to pull his weight" during the preparation and positioning of the tanks for the robotized welding and / or after the performance of the welding, when the tanks need to be moved again, from the robot to the next operation. The preparation, positioning and removal of the tanks are manual operations, where the operator can simply take more time than necessary, be it positioning the tank, or not removing the tank after it has been soldered by the robot. The choice of when to perform the operations is at the discretion of the operator.

Production line 47 possesses a theoretical manpower distribution, throughout the production process. Such distribution is called capacity frame. The capacity frame for this line foresees the need for 40 operators and two supervisors per shift in order to obtain maximum production with all the work places filled, respecting the logic of the takt time ${ }^{10}$. The takt time is measured by Codi, along the welding robots. While the robot is performing the welding operation, the Codi system is doing the reading and registering the times. Between the welding of one tank and another, the Codi system registers that the robot is not being used, which characterizes a waste of time in the process and the reduction of such time represents productivity gain. The function of the operator is to change the tanks at the end of each welding operation. Without adequate supervision it is very easy for the operator to adopt a shirking posture during the course of these exchanges.

According to data from the Human Resources department at Bruning,Line 47 presents a low turnover rate. Within the analyzed period for this work $(11 / 01 / 2010-10 / 31 / 2012)$, the turnover rate remained within the historical patterns of $3.7 \%$ per year. The mean time at the company for employees of

\footnotetext{
${ }^{8}$ As unexpected stops we can have: lack of electricity, production meetings, going to the toilet, etc.

${ }^{9}$ Bottleneck operation is one that presents the largest processing time.

${ }^{10}$ Time available for production divided by customer demand. For more details see Marchwinski \& Shook (2003).
} 
each shift during the period analyzed in this study was 2 years and 11 months for employees of the first shift and three years and four months for the second shift employees. It is important to say that within the sample period the number of workers in each group was constant and equal to 40. This is because each operator has a specific and unique function, so it is not possible to produce if someone is missing. Operators who missed work were immediately replaced.

Between November 2010 and October 2011 a modification was made in relation to the degree of supervision in production line 47 . During that period, one of the assembly line supervisors of the capacity frame of the second shift (Group 2), was eliminated. This modification did not take place in the first shift (Group 1), which continued having two supervisors.

Such modification was made due to the great difficulty of the company in finding qualified ${ }^{11}$ manpower for this function. This modification led to a change in the supervisors/supervised ratio with a difference of $50 \%$ between one shift and the other. For the first shift (Group 1) this ratio remained at $\frac{2}{40}=0.05$, however, for the second shift (Group 2), this ratio became $\frac{1}{40}=0.025$. In November 2011, the second supervisor of the second shift (Group 2) was replaced. With this, the supervisors/supervised ratio was the same again for both shifts (groups). Thus, between November 2011 and October 2012, both shifts (groups) maintained a supervisors/supervised ratio of $\frac{2}{40}=0.05$. Therefore, during the period of one year, the two groups operated with different supervision levels, which, according to the shirking model, as developed by Shapiro \& Stiglitz (1984), represented an opportunity for shirking behaviors, when "one is not pulling his weight", since the chance of an operator being caught practicing this type of posture was reduced.

While Group 1 (first shift) remained with two supervisors during two years (between November 2010 and October 2012), Group 2 (second shift) had one supervisor during the first year (between November 2010 and October 2011) and two supervisors during the second year (between November 2011 and October 2012). For each variable, in each group, 464 observations were generated regarding performance, efficiency and availability, which will be analyzed in the next section.

\section{Empirical Strategy}

First, as a consequence of the nature of available data and the theory model of efficiency wage, a hypothesis test for the mean of productivity between the two groups of workers was conduct. Specifically, the following two hypotheses were tested:

$H_{0}$ : Before the increase in the supervision level for Group 2, productivity was higher in Group 1 than in Group $2\left(P M_{1}>P M_{2}\right)$, therefore, the average productivity must be greater in Group 1 than in Group 2 without wage differentiation.

$H_{1}$ : after the increase of the supervision level in Group 2, the moral hazard of the group submitted to more supervision (Group 2) was reduced, becoming equal to that of Group $1\left(P M_{1}=P M_{2}\right)$, therefore, the average productivity of Group 1 should be equal to that of Group 2.

\footnotetext{
${ }^{11}$ For this function the minimum qualification for hiring is a mid-level technical course in mechanics.
} 
The tested groups were of the semi-closed type, with small alterations of the participants, due to the low turnover of the sector (3.7\% per year), keeping the other conditions constant (ceteris paribus), ensuring the lowest possible influence of the work environment, the degree of worker experience and even turnover. So, this was a real and timely case study where it was possible to work with more data and in a smaller universe than that evaluated by Gatica et al. (1995), Arbache (2001), Esteves (2006, 2008) and Uhr \& Ziero (2011), who used aggregate and sectorial data from the Brazilian economy. Second, with the objective of evaluating the effect of the increased degree of supervision on Group 2, a natural experiment ${ }^{12}$, the authors opted to use the differences-in-differences method. The choice of this empirical strategy is mainly justified for having information of two different groups on performance, efficiency and availability along time. In this case, the authors seek to evaluate the intervention through the increase in supervision in the production lines, focused on only one of the groups.

The central hypothesis for the identification of the impact in the increased supervision of Group 2 resides in assuming that, without the supervision increase on the second group, the performance, efficiency and availability of both groups would follow parallel trajectories. In other words, any other shocks that might affect the trajectories of the interest variables between the treated group and the control group would exert the same influence.

Therefore, any deviation observed in the trajectories of the interest variables between the two groups, in periods subsequent to the intervention, can be attributed to the effect of the supervision increase on Group 2.

Formally, the following equation will be estimated:

$$
Y_{i t}=\alpha_{0}+\alpha_{1} G_{i}+\alpha_{2} P_{t}+\alpha_{3} G_{i} P_{t}
$$

For $i=1,2$ and $t=1, \ldots, 464$.

The dependent variable $Y$ is both a measure of the production performance and a measure of efficiency and availability. While the variable $G$ is a binary variable that takes on value 1 for group 2 and value 0 for group 1 . Variable $P$ is also a binary variable that takes on value 1 for all the observations of periods after the 03/11/2011 (date of the beginning of the increased monitoring for group 2), and zero for the periods prior to that date.

The coefficient of interest to be estimated is $\alpha_{3}$ that captures the difference of the conditional differences of the dependent variable between the two groups throughout time. In order to visualize this, consider the four conditionals below:

$$
\begin{array}{r}
E\left[Y_{i t} \mid G_{i}=1, P_{i}=1\right]=\alpha_{0}+\alpha_{1}+\alpha_{2}+\alpha_{3}+E\left[\epsilon_{i t} \mid G_{i}=1, P_{i}=1\right] \\
E\left[Y_{i t} \mid G_{i}=1, P_{i}=0\right]=\alpha_{0}+\alpha_{1}+E\left[\epsilon_{i t} \mid G_{i}=0, P_{i}=1\right] \\
E\left[Y_{i t} \mid G_{i}=0, P_{i}=1\right]=\alpha_{0}+\alpha_{2}+E\left[\epsilon_{i t} \mid G_{i}=0, P_{i}=1\right] \\
E\left[Y_{i t} \mid G_{i}=0, P_{i}=0\right]=\alpha_{0}+E\left[\epsilon_{i t} \mid G_{i}=1, P_{i}=1\right]
\end{array}
$$

\footnotetext{
${ }^{12}$ According to Angrist \& Pischke (2014), natural experiments take place when an exogenous event occurs, generally some governmental policy change (of the firm), generating alterations in the environment in which the individuals, families or workers operate. In order to analyze a natural experiment one must always have a control group which has not been affected by the change and a treatment group that is affected by the event.
} 
From the differences $(a)-(b)$ and $(c)-(d)$ we obtain:

$$
\begin{array}{r}
(a)-(b)=\alpha_{2}+\alpha_{3}+E\left[\epsilon_{i t} \mid G_{i}=1, P_{i}=0\right]-E\left[\epsilon_{i t} \mid G_{i}=1, P_{i}=0\right] \\
(c)-(d)=\alpha_{2}+E\left[\epsilon_{i t} \mid G_{i}=1, P_{i}=1\right]-E\left[\epsilon_{i t} \mid G_{i}=1, P_{i}=0\right]
\end{array}
$$

Equation 3 was also estimated in three other specifications for checking the robustness of the estimated results. The second of the four specifications includes an interaction term between the binary variable that identifies the groups and a trend variable $(t)$. With this interaction, the trajectories of the dependent variables are allowed to have different tendencies between the two groups. In the third specification the interaction of the second is removed and dummies of months are included to control effects related to seasonal issues that might affect productivity and efficiency. In the fourth and last specification, both the interaction as well as the dummies of months are included. The standard errors were estimated by the White correction process for the covariance matrix. Furthermore, three different samples were used to perform the step described above.

In the first sample, all the available observations were used. This sample is referred to as the "Complete Sample". The second sample just contains information within the time frame of the 6 months before and after 11/03/2011. This sample was called "six months sample". Finally, the third sample contains observations within the month prior to and after 03/11/2011. This sample was named "one month sample". This procedure was adopted to investigate if the monitoring effect, in case it exists, presents some heterogeneous behavior over time. In the one month sample, only two specifications are estimated, those that do not include seasonal dummies, that in this case would be perfectly collinear with the variable P.

With the purpose of checking the validity of the results, two procedures were adopted. The first is referred to here as "temporal placebo". It consists of the estimation of all the specifications used with the alteration of the date of treatment for previous periods to the real supervision change in group 2 . The idea behind this procedure is to check the existence of trajectories previously not parallel between the dependent variables of the two groups, which invalidates the identification impact hypothesis of the differences in differences method in our case. If the results observed in the main estimations were in fact significant and were capturing the supervision effect on the performance and the efficiency, when the estimations for periods prior to the change of supervision policy are done, what is expected is an absence of statistical significance. In this procedure, the information generated after 11/03/2011 is not used, the purpose is not to contaminate the estimates of the temporal placebo with information of periods when the intervention is in effect.

The "temporal placebos" were estimated in two periods with different samples. The first is six months before the date of the intervention 05/02/2011, with a sample from $11 / 01 / 2010$ to $10 / 30 / 2011$, while the second one is a month before the date of intervention, $10 / 03 / 2011$, with a sample from $09 / 01 / 2011$ until 10/30/2011. The other checking procedure used for robustness consists in estimating all the specifications having the availability degree of the machines to work with as a dependent variable, which in principle should not be influenced by the supervision increase, since machines only suffer influence from structural factors such as the supply of electric energy, for instance, indicating that if there is no availability variation with the increase of supervision 
and there are productivity and efficiency variations, there are indications of robust results ${ }^{13}$.

\section{Results}

Before analyzing the results of the models based on the differences in differences method, some median tests were carried out, indicating different levels of productivity between groups before the supervision increase occurred in Group 2. From the values calculated in Table D.3. ${ }^{14}$, it can be stated that, from the statistical point of view, the medians for Productivity and Efficiency obtained between Group 1, with two supervisors and Group 2, with one supervisor, are statistically different. For the availability, the averages do not show significant statistical difference.

Productivity and efficiency are related to the performance of the production line workers. Availability, on the other hand, is related to the unexpected stops (maintenance problems, lack of electric energy, etc.). Thus, it is coherent with the shirking model not to find differences between the averages for availability, given that the difference in the number of supervisors does not have much influence on unexpected stops. Thus, hypothesis $H_{0}$ is thus confirmed.

With the insertion of the second supervisor in Group 2, based on Table D.1, it can be asserted that, statistically, the averages obtained for Performance, Efficiency and Availability among Group 1, with two supervisors, and Group 2 , with two supervisors, are not different. The $H_{1}$ hypothesis is confirmed this way. In addition to this average difference analysis between groups, the analysis of Group 2 itself was also performed, before and after the increase in supervision, in which, according to Table D.2, it was proved that the group, in relation to itself, obtained a significant increase with the introduction of one more supervisor. However, in order to investigate the shock effect of supervision that occurred in group 2 in more detail, the results of the differences in differences method are highlighted.

Table D.3, presents the estimates of differences in differences of the increased monitoring effect on Group 2, in terms of productivity. In the full sample, in three of the estimated specifications the effect is positive and statistically significant to $1.0 \%$. The estimated coefficients indicate that increased supervision generated, on average, an increase in daily performance in the range of $13.5 \%$ to $16.8 \%$. The estimations for the other two samples also corroborate the positive effect observed in the complete sample, with the effect of the increase in supervision over the second group being higher in the short term. In the six-month sample estimates are all significant at $1.0 \%$ and range from $16.3 \%$ to $19.3 \%$. In the one-month sample the estimated effects are also significant and are between $21.9 \%$ and $26.8 \%$. In the three samples the greater coefficients are associated with the model with the presence of the possibility of different trajectories of the dependent variables among the groups.

Table D.4, presents the results of the estimations where the dependent variable is efficiency. The results indicate that the monitoring is significant only in the six-month sample. The estimates range between $22.6 \%$ and $26,7 \%$.

\footnotetext{
${ }^{13}$ For an additional example of the falsification test see Williams \& Bretteville-Jensen (2014).

${ }^{14}$ Appendixes Appendix A and Appendix B highlight graphic analysis of the series. In Appendix Appendix B, are the tables with the estimated results.
} 
In the models with interaction between tendency and group, the coefficients were merely significant to $10 \%$.

The results of the "temporal placebo" estimates for performance can be observed in Table D.5. In the sample with six-month sample, the estimated coefficient was significant only in one of the four specifications. In the onemonth sample, no coefficient associated to the "false" intervention effect was significant. These results indicate that there were no different previous tendencies in the performance between the two groups. Therefore, the results presented in table A.4.1 are corroborated as an effect of the increased monitoring of Group 2 on the performance of the workers. Table A.4.7 presents the results of the temporal placebos for efficiency. In the six-month sample three coefficients are statistically significant, however there is no robustness in the placebo estimates. Positive and negative coefficients were observed. In the one-month sample there are no statistically significant coefficients.

Finally, Table D. 6 presents the differences-in-differences estimations over the availability variable. No coefficient, for any of the three samples, indicates effect of the monitoring. As it was previously discussed, there is no reason whatsoever for availability to suffer any change due to increase in monitoring. The absence of statistical significance in the estimated coefficients for availability, reinforces the robustness of the results we observed mainly for the worker productivity. Therefore, it is evaluated that the estimates present in Table D. 3 are not spurious, because if they were, it would be reasonable to imagine finding statistical significance in the estimations where availability is the dependent variable.

From the verification that there was an increase in productivity with the supervision increase in Group 2, the result mentioned by Shapiro and Stiglitz (1984), that is, an inverse relationship between supervision and wages, is reached. Since no differentiation was made at the wage level among the workers allocated to the first and second shift, in spite of the elimination of the supervisor position for the second shift (between November 2010 and October 2011), it was to be expected that the production level of the second shift (Group 2) would present a reduction to the level of the first shift (Group 1) $H_{0}$ and a productivity increase in group 2 after the $H_{1}$ shock. Such condition was justified, mainly due to the modification of the detection probability $(q)$ of the "not pulling one's weight" (shirking model), that was reduced by half with the elimination of a supervisor $\left(q_{1} \neq q_{2}\right)$. Supposing that before the detection probability of the "not pulling one's weight" condition was $\left(q_{1}=50 \%\right)$, in the second moment we have the reduction in half $\left(q_{2}=25 \%\right)$. Next, a simulation for the case being analyzed is conducted.

Table D.7 below presents a synthesis of the mains results of the effects of supervision on the productivity and efficiency. It also shows the results of the robustness check that use availability as the dependent variable (placebo).

In addition to the econometric analysis, a simulation exercise was held. Using Equation 2 it is possible to perform a simulation exercise and calculate the wage that should be put into practice, in order to maintain the worker effort level, even with the reduction in supervision level and consequent reduction of detection probability $(q)$ of the shirking behavior (wage efficiency).

$$
\left.w \geq e+\dot{w}+\left(\frac{e}{q}\right)\left(\frac{b}{u}+r\right)\right)
$$


Table 1: Monitoring Effect on Performance, Efficiency and Availability (Placebo)

\begin{tabular}{|c|c|c|c|c|c|c|c|c|c|}
\hline & \multicolumn{3}{|c|}{$\begin{array}{c}\text { Full Sample } \\
(01 / 11 / 2010-30 / 10 / 2012)\end{array}$} & \multicolumn{3}{|c|}{$\begin{array}{c}\text { Six month sample } \\
(02 / 05 / 2011-30 / 04 / 2012)\end{array}$} & \multicolumn{3}{|c|}{$\begin{array}{c}\text { One month sample } \\
(03 / 10 / 2011-30 / 11 / 2011)\end{array}$} \\
\hline & Perf. & Effi. & Aval. & Perf. & Effi. & Aval. & Perf. & Effi. & Aval. \\
\hline Monitoring effect & $\begin{array}{l}0,168^{* * *} \\
(-0,033)\end{array}$ & $\begin{array}{l}0,283^{* * *} \\
(-0,104)\end{array}$ & $\begin{array}{l}0,099 \\
(-0,090)\end{array}$ & $\begin{array}{l}0,168^{* * *} \\
(-0,046)\end{array}$ & $\begin{array}{l}0,226^{*} \\
(-0,127)\end{array}$ & $\begin{array}{l}0,038 \\
(-0,110)\end{array}$ & $\begin{array}{l}0,268^{* * *} \\
(-0,089)\end{array}$ & $\begin{array}{l}0,267 \\
(-0,202)\end{array}$ & $\begin{array}{l}0,030 \\
(-0,157)\end{array}$ \\
\hline Group 2 & $\begin{array}{c}-0,104^{* * * *} \\
(-0,018)\end{array}$ & $\begin{array}{c}-0,028 \\
(-0,054)\end{array}$ & $\begin{array}{l}0,026 \\
(-0,049)\end{array}$ & $\begin{array}{c}-0,117^{* *} \\
(-0,056)\end{array}$ & $\begin{array}{c}-0,221 \\
(-0,153)\end{array}$ & $\begin{array}{c}-0,107 \\
(-0,129)\end{array}$ & $\begin{array}{l}0,512 \\
(-0,797)\end{array}$ & $\begin{array}{l}0,719 \\
(-1,627)\end{array}$ & $\begin{array}{l}0,264 \\
(-1,367)\end{array}$ \\
\hline Constant & $\begin{array}{l}4,314^{* * *} \\
(-0,016)\end{array}$ & $\begin{array}{l}3,901^{* * *} \\
(-0,043)\end{array}$ & $\begin{array}{l}4,219^{* * * *} \\
(-0,038)\end{array}$ & $\begin{array}{l}4,347^{* * * *} \\
(-0,027)\end{array}$ & $\begin{array}{l}3,856^{* * *} \\
(-0,053)\end{array}$ & $\begin{array}{l}4,101^{* * *} \\
(-0,038)\end{array}$ & $\begin{array}{l}4,338^{* * *} \\
(-0,035)\end{array}$ & $\begin{array}{l}3,819^{* * *} \\
(-0,062)\end{array}$ & $\begin{array}{l}4,095^{* * *} \\
(-0,039)\end{array}$ \\
\hline $\mathrm{R}^{2}$ & 0,326 & 0,352 & 0,341 & 0,283 & 0,55 & 0,567 & 0,303 & 0,033 & 0,024 \\
\hline R2 Adjusted & 0,315 & 0,341 & 0,33 & 0,26 & 0,536 & 0,553 & 0,26 & $-0,026$ & $-0,036$ \\
\hline Observations & 928 & 927 & 927 & 460 & 459 & 459 & 70 & 70 & 70 \\
\hline Tendency & Yes & Yes & Yes & Yes & Yes & Yes & Yes & Yes & Yes \\
\hline Seasonality & Yes & Yes & Yes & Yes & Yes & Yes & - & - & - \\
\hline
\end{tabular}

Note: *** $p<0.01, * * p<0.05, * p<0$

Source: Own Elaboration parting from the results. 
Since there were no modifications in the salaries paid to the production line workers throughout time, the salaries paid between $t_{0}$ and $t_{1}$ were the same as between $t_{1}$ and $t_{2}\left(w_{1}=w_{2}\right)$.

Effort (e) would also remain the same, as well as unemployment payment $(\bar{w})$. Therefore, it can reasonably be argued that employee discount rate $(r)$ also does not suffer alteration, that frictional unemployment $(b)$ remains stable and that unemployment wage $(\bar{w})$ for an employee who earns US $\$ 496,02$ per month is US\$388,861. Considering frictional unemployment of $(b=1 \%)$ and the 2010 rate of unemployment as $(u=6,7 \%)$, we have that:

$$
w_{1} \geq e_{1}+\dot{w}+\left(\frac{e_{1}}{q_{1}}\right) \cdot\left(\frac{b}{u}+r\right) \rightarrow 496.02 \geq e_{1}+388.86+\left(\frac{e_{1}}{0.5}\right) \cdot\left(\frac{0.01}{0.067}+1\right)
$$

\section{$e_{1} \geq 31.62$}

Since the effort is the same in both moments, it is possible to calculate what the wage to be paid with the supervision reduction $(q)$ so as to maintain a constant effort level.

$$
\begin{array}{r}
w_{2} \geq e_{1}+\dot{w}+\left(\frac{e_{1}}{q_{2}}\right) \cdot\left(\frac{b}{u}+r\right) \\
+\left(\frac{55.6615}{0.25}\right) \cdot\left(\frac{0.01}{0.067}+1\right)
\end{array}
$$

$w_{2} \geq U S \$ 568.71 \quad w_{2} \geq R \$ 568.71 \quad w_{2} \geq R \$ 1,000.9382$, a wage $14,66 \%$ higher than the current wage paid.

Yet, as the wage $(w)$ remains constant, it is to be expected that the effort level would have a significant reduction due to the modification of the detection probability (q) of the "not pulling one's weight" (shirking model).

$$
w_{2} \geq e_{2}+\dot{w}+\left(\frac{e_{2}}{q_{2}}\right) \cdot\left(\frac{b}{u}+r\right) \rightarrow 496.02 \geq e_{2}+388.86+\left(\frac{e_{2}}{0.25}\right) \cdot\left(\frac{0.01}{0.067}+1\right)
$$

$e_{2} \geq 32.8032 e_{2} \geq 18.63$, a $41.08 \%$ reduction in the effort level.

In order to maintain the effort level, according to the Shapiro \& Stiglitz (1984) model, it would be necessary to increase the wage of the 40 workers(machine operators by $14.66 \%$ (from US\$ 496.02 to US\$ 568.71 ) This would represent an increase in the production costs (ceteris paribus) of US\$2,907.62 ((US\$ 568.71 - US\$ 496.02).40). Considering that the wage of the supervisor is US\$ $624.98^{15}$, in case it is possible to maintain the productivity level by adding one more supervisors, such option proves to be less costly than practicing a wage efficiency policy. In the Bruning case, the economic advantage of working with one more supervisor becomes evident, since the additional costs imposed by the hiring and maintenance of this added worker are much lower than the gains obtained through a higher productivity of the welding line of the fuel tanks, thanks to a reduction of the "shirking behavior".

\footnotetext{
${ }^{15}$ Net wage, without social security charges
} 


\section{Final Considerations}

The objective of this work was to test the existence of a trade-off between supervision and wage, using the efficiency wage model, more specifically the shirking model, Shapiro \& Stiglitz (1984) for data obtained from the Bruning Tecnometal Ltda company in the production line of aluminium fuel tanks, based on the Insider Econometrics approach. The relevance of the present study is that it shows how productivity can be increased, showing its fundamentals as well as the measurement of results are.

The analysis of the series indicated that there was an increase in productivity as soon as the level of supervision increased. Besides, the econometric tests indicate the existence of the positive correlation according to Shapiro \& Stiglitz (1984) and is confirmed for the Bruning case. The results point to the increased daily average productivity of the workers who belong to Group 2 after the increase in supervision. The estimated effect is ranges between $13.5 \%$ and $26.8 \%$ depending on the the sample estimation. The results are robust to different distortion strategies. Since the efficiency of the estimated results is significant in only one of the samples used, this does not allow us to accomplish an accurate analysis of the effect of increased supervision on this variable.

The main conclusion of this study is that after the confirmation that the two working hypothesis proved to be significant from the statistical point of view, the firm can choose between the addition of one more supervisor, with a cost of U\$ 624.98 instead of practicing an efficiency wage for all the 40 workers who operate machines in the production line.

Through the calculation of the theoretical model, the increase over the wage should be $14.66 \%$ to maintain the same level of effort, for the 40 assembly line operators. Such increase would represent an additional cost of US\$ $2,907.72$. In this way, in case the firm chooses to add one more supervisor (wage of US\$ 624,98) instead of practicing efficiency salaries (US\$2,907.72), it would reduce the cost by US\$2,282.74. Thus, it becomes more advantageous for the company to increase the number of supervisors instead of increasing wages.

\section{Bibliography}

Angrist, J. D. \& Pischke, J. S. (2014), Mastering Metrics: The path from cause to effect, Princeton University.

Arbache, J. S. (2001), 'Trade liberalisation and labour market in developing countries: theory and evidence.', University of Kent . Department of Economics Discussion Paper 01/12.

Bandiera, O., Barankay, I. \& Rasul, I. (2005), 'Social preferences and the response to incentives: evidence from personnel data', Quarterly Journal of Economics 120, 917-196.

Bandiera, O., Barankay, I. \& Rasul, I. (2007), 'Incentives for managers and inequality among workers: Evidence from a firm-level experiment.', The Quarterly Journal of Economics 122(2), 729-773. 
Bandiera, O., Barankay, I. \& Rasul, I. (2009), 'Social connections and incentives in the workplace: Evidence from personnel data', Econometrica 77(4), 1047-1094.

Bartel, A., Ichniowski, C. \& Shaw, K. (2004), 'Using “insider econometrics” to study productivit', The American Economic Review 94(2), 217-223.

Esteves, L. A. (2006), 'Uma nota sobre intensidade de supervisão nas indústrias brasileiras', Revista Brasileira de Economia, 60, 235-246.

Esteves, L. A. (2008), 'Salário eficiência e esforço de trabalho: evidências da indústria brasileira de construção', Revista Economia 9(2), 327-341.

Franceschelli, I., Galiani, S. \& Gulmez, E. (2010), 'Performance pay and productivity of low-and high-ability workers', Labour Economics 17(2), 317-322.

Freeman, R. \& Kleiner, M. (2005), 'The last american shoe manufacturer: Decreasing productivity and increasing profits in the shift from piece rates to continuous flow production', Industrial Relations 44(2), 307-330.

Frick, B. J., Goetzen, U. \& Simmons, R. (2013), 'The hidden costs of highperformance work practices: Evidence from a large german steel company', Industrial \& Labor Relations Review 66(1), 198-224.

Gatica, J., Mizala, A. \& Romaguera, P. (1995), 'Interindustry wage differentials in brazil', Economic Development and Cultural Change 43(2), 315-331.

Hamilton, B. H., Nickerson, J. A. \& Owan, H. (2003), 'Team incentives and worker heterogeneity: An empirical analysis of the impact of teams on productivity and participation', Journal of Political Economy 111(3), 465-497.

IBGE (2010), 'Dados do censo 2010'.

URL: http://www.censo2010.ibge.gov.br/sinopse/webservice/frm_piramide.php ?codigo $=431390$ E corhomem $=3 d 4590$ Ecormulher $=9 \mathrm{cdbfc}$

Ichniowski, C. \& Shaw, K. (2013), Insider econometrics, in R. Gibbons \& J. Roberts, eds, 'The Handbook of Organizational Economics', Scottdale, Princeton, chapter 7, pp. 261-311.

Jones, D. C., Kalmi, P. \& Kauhanen, A. (2008), Overview and evidence from recent finnish studies. Working paper.

Jones, D. C., Kalmi, P. \& Kauhanen, A. (2010), 'Teams, incentive pay, and productive efficiency: Evidence from a food-processing plant', Industrial $\mathcal{E}$ Labor Relations Review 63(4), 606-626.

Jones, D. C. \& Kato, T. (2006), The impact of teams on output, quality and downtime: An empirical analysis using individual panel data. Working Paper, Hamilton College.

Knez, M. \& Simester, D. (2001), 'Firm-wide incentives and mutual monitoring at continental airlines', Journal of labor Economics 19(4), 743-772.

Lazear, E. P. (2000), 'Performance pay and productivity', American Economic Review 90(5), 1346-1361. 
Lazear, E. P. \& Shaw, K. (2007), 'Personnel economics: The economist's view of human resources', Journal of Economic Perspectives 21(4), 91-114.

Marchwinski, C. \& Shook, J. (2003), Lean lexicon: a graphical glossary for lean thinkers, Lean Enterprise Institute.

Paarsch, H. J. \& Shearer, B. S. (2000), 'Piece rates, fixed wages and incentive effects: Statistical evidence from payroll records', International Economics Review 41(1), 59-92.

Raff, D. M. \& Summers, L. H. (1987), 'Did henry ford pay efficiency wages?', Journal of Labor Economics 5(4).

Shapiro, C. \& Stiglitz, J. E. (1984), 'Equilibrium unemployment as a worker discipline device', American Economic Review 74, 433-444.

Shaw, K. (2009), 'Insider econometrics: a roadmap with stops along the way', Labour Economics 16, 607-617.

Shearer, B. S. (2004), 'Piece rate, fixes wages and incentives: Evidence from a field experiment', Review of Economic Studies 71(2), 513-534.

Stiglitz, J. E. (2009), Selected Works of Joseph E. Stiglitz, Vol. 1, Oxford University Press, Oxford.

Uhr, D. A. P. \& Ziero, J. G. (2011), 'Existe trade off entre supervisão e salários? evidencias para a indústria da construção civil brasileira', Anpec Sul .

Williams, J. \& Bretteville-Jensen, A. L. (2014), 'Does liberalizing cannabis laws increase cannabis use?', Journal of Health Economics 36(24), 20-32.

\section{Appendix A}


Table A.1: Main papers about Personnel Economics with a single firm data.

\begin{tabular}{|c|c|c|c|c|c|c|}
\hline Authors & Year & Research Question & Type of Acitivity & Unit Observation & Frequency & Main Results \\
\hline Lazear (2000) & 2000 & $\begin{array}{l}\text { Productivity and sort- } \\
\text { ing effects of piece rate }\end{array}$ & windshield installing & Individual & Monthly & $\begin{array}{l}\text { Adoption of piece rate improve produc- } \\
\text { tivity by } 44 \%\end{array}$ \\
\hline Paarsch \& Shearer (2000) & 2000 & $\begin{array}{l}\text { Productivity effects of } \\
\text { piece rates }\end{array}$ & Tree planting & Individual & Daily & $\begin{array}{l}\text { Piece rates increase productivity at least } \\
23 \%\end{array}$ \\
\hline Knez \& Simester (2001) & 2001 & $\begin{array}{l}\text { Impact of profit-sharing } \\
\text { on-time departures }\end{array}$ & Airport departures & Airport & Monthly & $\begin{array}{l}\text { Profit-Sharing improves on-time depar- } \\
\text { tures }\end{array}$ \\
\hline Hamilton et al. (2003) & 2003 & $\begin{array}{l}\text { Productivity and sort- } \\
\text { ing effects to team com- } \\
\text { pensation }\end{array}$ & Textile & Individual & Weekly & $\begin{array}{l}\text { Adoption of team leads to } 14 \% \text { produc- } \\
\text { tivity increase }\end{array}$ \\
\hline Shearer (2004) & 2004 & $\begin{array}{l}\text { Productivity effects of } \\
\text { piece rate }\end{array}$ & Tree planting & Individual & Daily & $\begin{array}{l}\text { Piece rates increase productivity at least } \\
22 \%\end{array}$ \\
\hline Bartel et al. (2004) & 2004 & $\begin{array}{l}\text { Impact of HRM on sales } \\
\text { growth }\end{array}$ & Banking & Branch & Yearly & $\begin{array}{l}\text { Some elements of the HRM environment } \\
\text { improve perfomance }\end{array}$ \\
\hline Bandiera et al. (2005) & 2005 & $\begin{array}{l}\text { Productivity and effects } \\
\text { of relative vs. absolute } \\
\text { incentive }\end{array}$ & Fruit picking & Individual & Daily & Piece rates increase productivity by $59 \%$ \\
\hline Freeman \& Kleiner (2005) & 2005 & $\begin{array}{l}\text { Productivity and profits } \\
\text { after the change from } \\
\text { piece to time rates }\end{array}$ & Shoes manufacturing & Plant & Monthly & $\begin{array}{l}\text { Shift from piece to time rates decrease } \\
\text { productivity and wages but increase } \\
\text { profits }\end{array}$ \\
\hline Jones \& Kato (2006) & 2006 & $\begin{array}{l}\text { Performance effects of } \\
\text { off-line teams }\end{array}$ & Light manufacturing & Individual & Daily & $\begin{array}{l}\text { Off-line teams increase productivity by } \\
3 \% \text {. Effects dissipate over time. }\end{array}$ \\
\hline Bandiera et al. (2007) & 2007 & Pay and performance & soft fruit & Individual & Daily & $\begin{array}{l}\text { Managerial performance pay raises both } \\
\text { the mean and the dispersion of produc- } \\
\text { tivity }\end{array}$ \\
\hline Bandiera et al. (2009) & 2009 & $\begin{array}{l}\text { Social connections and } \\
\text { incentives }\end{array}$ & soft fruit & Individual & Daily & $\begin{array}{l}\text { Payment schemes alterer managers be- } \\
\text { haviours in relation their social connec- } \\
\text { tions. }\end{array}$ \\
\hline Franceschelli et al. (2010) & 2010 & $\begin{array}{l}\text { Productivity and effects } \\
\text { of piece rate }\end{array}$ & Textile & Individual & Daily & $\begin{array}{l}\text { Piece-rate plus basic-wage scheme has } \\
\text { an effect on productivity of } 28 \%\end{array}$ \\
\hline Jones et al. (2010) & 2010 & $\begin{array}{l}\text { Impact of HRM on pro- } \\
\text { ductivity }\end{array}$ & Food-processing & Production Lines & Weeks & $\begin{array}{l}\text { There is a joint effect of teams and per- } \\
\text { formance related pay. }\end{array}$ \\
\hline Frick et al. (2013) & 2013 & $\begin{array}{l}\text { Impact of HRM on pro- } \\
\text { ductivity, accidents and } \\
\text { absence rates }\end{array}$ & steel-producing & production unit & Monthly & $\begin{array}{l}\text { A quality-adjusted measure of output } \\
\text { does not reveal benefits from teamwork } \\
\text { or performance-related pay. }\end{array}$ \\
\hline
\end{tabular}




\section{Appendix B}

Figure B.1: Graphic Analysis of the series before and after the supervision shock
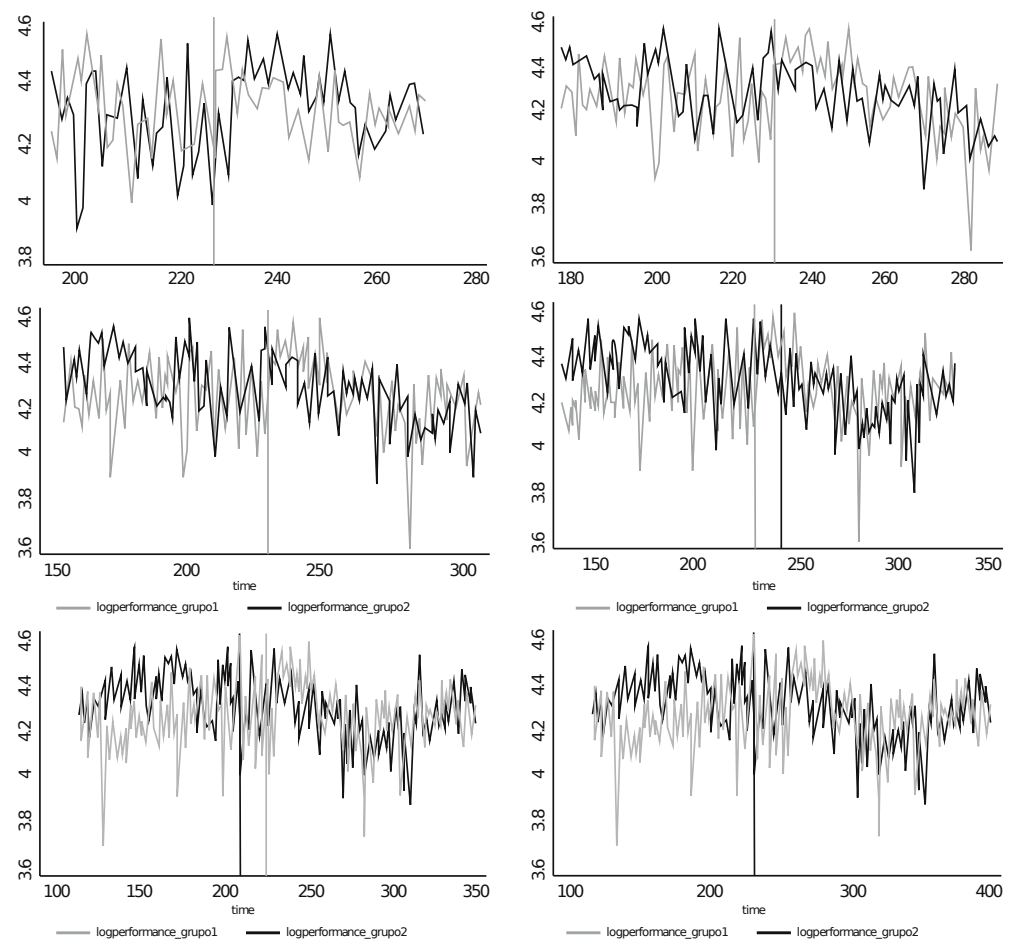

Source: Own elaboration parting from the results. 


\section{Appendix C}

Figure C.1: Graphic Analysis of the productivity gap between groups
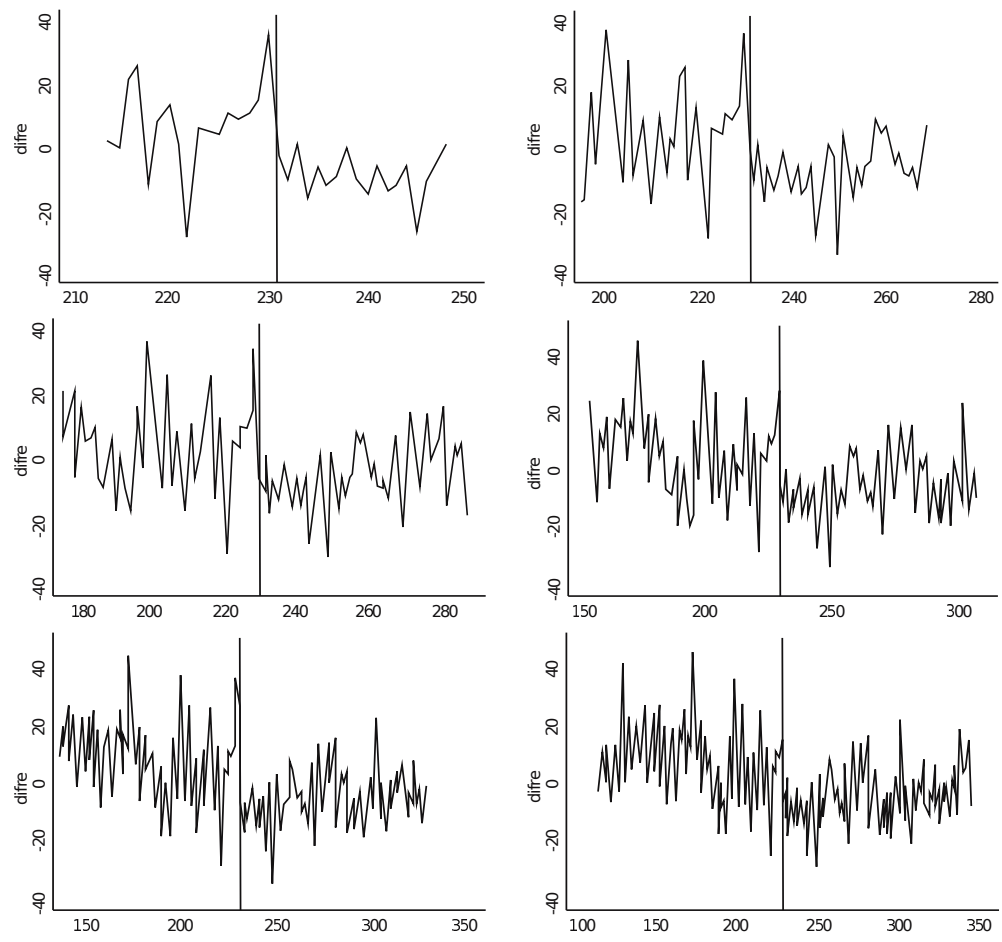

Source: Own elaboration parting from the results. 


\section{Appendix D}

Table D.1: Test of mean differences Group 1 (with 2 supervisors) against Group 2 (with 1 supervisor)

\begin{tabular}{lllc}
\hline \multicolumn{2}{c}{ Performance } & \multicolumn{2}{c}{ Efficiency } \\
\hline $\bar{d}$ & 8,224761 & $\bar{d}$ & 5,106076 \\
$S_{d}$ & 12,78741 & $S_{d}$ & 13,7883 \\
$S_{\bar{d}}$ & 0,815296 & $S_{\bar{d}}$ & 0,87911 \\
$t$ & 10,08807 & $t$ & 5,808234 \\
\hline \multicolumn{3}{l}{ Source: Elaborated by the author } \\
\multicolumn{3}{l}{$(2014)$}
\end{tabular}

Table D.2: Test of mean differences - Group 1 (with 2 supervisors) against Group 2 (with 2 supervisors)

\begin{tabular}{llll}
\hline \multicolumn{2}{c}{ Performance } & \multicolumn{2}{c}{ Efficiency } \\
\hline $\bar{d}$ & $-1,24905$ & $\bar{d}$ & 0,397409 \\
$S_{d}$ & 9,270631 & $S_{d}$ & 12,96114 \\
$S_{\bar{d}}$ & 0,591074 & $S_{\bar{d}}$ & 0,826372 \\
$t$ & $-2,11319$ & $t$ & 0,480908 \\
\hline \multicolumn{3}{l}{ Source: Elaborated by the author } \\
\multicolumn{3}{l}{ (2014) }
\end{tabular}

Table D.3: Difference between means test based on pairs of observations - Group 2 (with 1 supervisor) against Group 2 (with 2 supervisors)

\begin{tabular}{llll}
\hline \multicolumn{2}{c}{ Performance } & \multicolumn{2}{c}{ Efficiency } \\
\hline $\bar{d}$ & $-7,85312$ & $\bar{d}$ & 5,451354 \\
$S_{d}$ & 12,16165 & $S_{d}$ & 17,26995 \\
$S_{\bar{d}}$ & 0,775398 & $S_{\bar{d}}$ & 1,101092 \\
$t$ & $-10,1279$ & $t$ & 4,950861 \\
\hline \multicolumn{3}{l}{ Source: Elaborated by the author } \\
\multicolumn{2}{c}{ (2014) }
\end{tabular}


Table D.4: Estimates of the Monitoring Effect on Performance

\begin{tabular}{|c|c|c|c|c|c|c|c|c|c|c|}
\hline & \multicolumn{4}{|c|}{$\begin{array}{c}\text { Full Sample } \\
(01 / 11 / 2010-30 / 10 / 2012)\end{array}$} & \multicolumn{4}{|c|}{$\begin{array}{c}\text { Six month sample } \\
(02 / 05 / 2011-30 / 04 / 2012)\end{array}$} & \multicolumn{2}{|c|}{$\begin{array}{c}\text { One month sample } \\
(03 / 10 / 2011-30 / 11 / 2011)\end{array}$} \\
\hline & coef/se & coef/se & coef/se & coef/se & coef/se & coef/se & coef/se & coef/se & coef/se & coef/se \\
\hline Monitoring effect & $\begin{array}{l}0,135^{* * *} \\
(-0,018)\end{array}$ & $\begin{array}{l}0,047 \\
(-0,031)\end{array}$ & $\begin{array}{l}0,135^{* * *} \\
(-0,016)\end{array}$ & $\begin{array}{l}0,168^{* * *} \\
(-0,033)\end{array}$ & $\begin{array}{l}0,163^{* * *} \\
(-0,025)\end{array}$ & $\begin{array}{l}0,193^{* * *} \\
(-0,043)\end{array}$ & $\begin{array}{l}0,163^{* * *} \\
(-0,023)\end{array}$ & $\begin{array}{l}0,168^{* * *} \\
(-0,046)\end{array}$ & $\begin{array}{l}0,219^{* * *} \\
(-0,058)\end{array}$ & $\begin{array}{l}0,268^{* * *} \\
(-0,089)\end{array}$ \\
\hline Group 2 & $\begin{array}{c}-0,121^{* * *} \\
(-0,014)\end{array}$ & $\begin{array}{c}-0,165^{* * *} \\
(-0,019)\end{array}$ & $\begin{array}{c}-0,121^{* * * *} \\
(-0,012)\end{array}$ & $\begin{array}{c}-0,104^{* * *} \\
(-0,018)\end{array}$ & $\begin{array}{c}-0,125^{* * * *} \\
(-0,017)\end{array}$ & $\begin{array}{c}-0,080 \\
(-0,050)\end{array}$ & $\begin{array}{c}-0,125^{* * * *} \\
(-0,017)\end{array}$ & $\begin{array}{c}-0,117^{* * *} \\
(-0,056)\end{array}$ & $\begin{array}{r}-0,110^{* * *} \\
(-0,050)\end{array}$ & $\begin{array}{l}0,512 \\
(-0,797)\end{array}$ \\
\hline Post $01 / 11 / 2011$ & $\begin{array}{c}-0,019 \\
(-0,012)\end{array}$ & $\begin{array}{c}-0,019 \\
(-0,012)\end{array}$ & $\begin{array}{c}-0,020^{*} \\
(-0,011)\end{array}$ & $\begin{array}{c}-0,020^{*} \\
(-0,011)\end{array}$ & $\begin{array}{c}-0,115^{* * * *} \\
(-0,016)\end{array}$ & $\begin{array}{c}-0,115^{* * *} \\
(-0,016)\end{array}$ & $\begin{array}{r}-0,062^{* * *} \\
(-0,030)\end{array}$ & $\begin{array}{r}-0,063^{*} \\
(-0,033)\end{array}$ & $\begin{array}{l}0,001 \\
(-0,041)\end{array}$ & $\begin{array}{l}0,001 \\
(-0,041)\end{array}$ \\
\hline Constant & $\begin{array}{l}4,308^{* * *} \\
(-0,009)\end{array}$ & $\begin{array}{l}4,308^{* * *} \\
(-0,009)\end{array}$ & $\begin{array}{l}4,321^{* * * *} \\
(-0,015)\end{array}$ & $\begin{array}{l}4,314^{* * *} \\
(-0,016)\end{array}$ & $\begin{array}{l}4,364^{* * *} \\
(-0,011)\end{array}$ & $\begin{array}{l}4,364^{* * * *} \\
(-0,011)\end{array}$ & $\begin{array}{l}4,346^{* * *} \\
(-0,026)\end{array}$ & $\begin{array}{l}4,347^{* * *} \\
(-0,027)\end{array}$ & $\begin{array}{l}4,338^{* * * *} \\
(-0,034)\end{array}$ & $\begin{array}{l}4,338^{* * *} \\
(-0,035)\end{array}$ \\
\hline $\mathrm{R}^{2}$ & 0,112 & 0,126 & 0,325 & 0,326 & 0,122 & 0,123 & 0,283 & 0,283 & 0,298 & 0,303 \\
\hline $\mathrm{R}^{2}$ Adjusted & 0,109 & 0,122 & 0,314 & 0,315 & 0,116 & 0,116 & 0,262 & 0,26 & 0,266 & 0,26 \\
\hline Observations & 928 & 928 & 928 & 928 & 460 & 460 & 460 & 460 & 70 & 70 \\
\hline Tendency & No & Yes & No & Yes & No & Yes & No & Yes & No & Yes \\
\hline Seasonality & No & No & Yes & Yes & No & No & Yes & Yes & - & - \\
\hline
\end{tabular}

Source: Own Elaboration parting from the results. 
Table D.5: Estimates of Monitoring effect on Efficiency

\begin{tabular}{|c|c|c|c|c|c|c|c|c|c|c|}
\hline & \multicolumn{4}{|c|}{$\begin{array}{c}\text { Full sample } \\
(01 / 11 / 2010-30 / 10 / 2012)\end{array}$} & \multicolumn{4}{|c|}{$\begin{array}{c}\text { Six month sample } \\
(02 / 05 / 2011-30 / 04 / 2012)\end{array}$} & \multicolumn{2}{|c|}{$\begin{array}{c}\text { One month window } \\
(03 / 10 / 2011-30 / 11 / 2011)\end{array}$} \\
\hline & coef/se & coef/se & coef/se & coef/se & coef/se & coef/se & coef/se & coef/se & coef/se & coef/se \\
\hline Monitoring effect & $\begin{array}{l}0,070 \\
(-0,062)\end{array}$ & $\begin{array}{l}-0,024 \\
(-0,110)\end{array}$ & $\begin{array}{l}0,071 \\
(-0,053)\end{array}$ & $\begin{array}{l}0,283^{* * *} \\
(-0,104)\end{array}$ & $\begin{array}{l}0,260^{* * * *} \\
(-0,092)\end{array}$ & $\begin{array}{l}0,267^{*} \\
(-0,145)\end{array}$ & $\begin{array}{l}0,260^{* * *} \\
(-0,067)\end{array}$ & $\begin{array}{l}0,226^{*} \\
(-0,127)\end{array}$ & $\begin{array}{l}0,204 \\
(-0,145)\end{array}$ & $\begin{array}{l}0,267 \\
(-0,202)\end{array}$ \\
\hline Group 2 & $\begin{array}{c}-0,134^{* * *} \\
(-0,032)\end{array}$ & $\begin{array}{c}-0,181^{* * *} \\
(-0,056)\end{array}$ & $\begin{array}{c}-0,134^{* * *} \\
(-0,033)\end{array}$ & $\begin{array}{c}-0,028 \\
(-0,054)\end{array}$ & $\begin{array}{c}-0,170^{* * *} \\
(-0,041)\end{array}$ & $\begin{array}{c}-0,159 \\
(-0,141)\end{array}$ & $\begin{array}{c}-0,170^{* * *} \\
(-0,041)\end{array}$ & $\begin{array}{c}-0,221 \\
(-0,153)\end{array}$ & $\begin{array}{c}-0,082 \\
(-0,085)\end{array}$ & $\begin{array}{l}0,719 \\
(-1,627)\end{array}$ \\
\hline Post $01 / 11 / 2011$ & $\begin{array}{c}-0,309^{* * * *} \\
(-0,038)\end{array}$ & $\begin{array}{c}-0,309^{* * * *} \\
(-0,038)\end{array}$ & $\begin{array}{c}-0,311^{* * * *} \\
(-0,031)\end{array}$ & $\begin{array}{c}-0,312^{* * * *} \\
(-0,031)\end{array}$ & $\begin{array}{c}-0,519^{* * * *} \\
(-0,058)\end{array}$ & $\begin{array}{c}-0,519^{* * * *} \\
(-0,058)\end{array}$ & $\begin{array}{c}-0,256^{* * * *} \\
(-0,080)\end{array}$ & $\begin{array}{c}-0,298^{* * * *} \\
(-0,086)\end{array}$ & $\begin{array}{c}-0,084 \\
(-0,109)\end{array}$ & $\begin{array}{c}-0,084 \\
(-0,109)\end{array}$ \\
\hline Constant & $\begin{array}{l}3,773^{* * *} \\
(-0,020)\end{array}$ & $\begin{array}{l}3,773^{* * * *} \\
(-0,020)\end{array}$ & $\begin{array}{l}3,941^{* * *} \\
(-0,042)\end{array}$ & $\begin{array}{l}3,901^{* * *} \\
(-0,043)\end{array}$ & $\begin{array}{l}3,848^{* * * *} \\
(-0,024)\end{array}$ & $\begin{array}{l}3,848^{* * *} \\
(-0,024)\end{array}$ & $\begin{array}{l}3,811^{* * * *} \\
(-0,053)\end{array}$ & $\begin{array}{l}3,856^{* * *} \\
(-0,053)\end{array}$ & $\begin{array}{l}3,819^{* * *} \\
(-0,062)\end{array}$ & $\begin{array}{l}3,819^{* * *} \\
(-0,062)\end{array}$ \\
\hline $\mathrm{R}^{2}$ & 0,088 & 0,089 & 0,348 & 0,352 & 0,151 & 0,151 & 0,550 & 0,550 & 0,031 & 0,033 \\
\hline $\mathrm{R}^{2}$ Adjusted & 0,085 & 0,085 & 0,338 & 0,341 & 0,145 & 0,143 & 0,537 & 0,536 & $-0,013$ & $-0,026$ \\
\hline Observations & 927 & 927 & 927 & 927 & 459 & 459 & 459 & 459 & 70 & 70 \\
\hline Tendency & No & Yes & No & Yes & No & Yes & No & Yes & No & Yes \\
\hline Seasonality & No & No & Yes & Yes & No & No & Yes & Yes & - & - \\
\hline
\end{tabular}

Note: ${ }^{* * *} p<0.01,{ }^{* *} p<0.05,{ }^{*} p<0.1$

Source: Own elaboration parting from the results. 
Table D.6: “Temporal Placebo" Performance

\begin{tabular}{|c|c|c|c|c|c|c|}
\hline & \multicolumn{4}{|c|}{$\begin{array}{c}\text { Six month sample } \\
(01 / 11 / 2010-31 / 10 / 2011)\end{array}$} & \multicolumn{2}{|c|}{$\begin{array}{c}\text { One month window } \\
(01 / 09 / 2011-31 / 10 / 2011)\end{array}$} \\
\hline & coef/se & $\mathrm{coef} / \mathrm{se}$ & coef/se & coef/se & coef/se & coef/se \\
\hline Monitoring effect & $\begin{array}{l}-0,009 \\
(-0,027)\end{array}$ & $\begin{array}{l}0,054 \\
(-0,044)\end{array}$ & $\begin{array}{l}-0,009 \\
(-0,024)\end{array}$ & $\begin{array}{r}-0,097^{* *} \\
(-0,047)\end{array}$ & $\begin{array}{l}-0,061 \\
(-0,071)\end{array}$ & $\begin{array}{l}-0,039 \\
(-0,099)\end{array}$ \\
\hline Group 2 & $\begin{array}{c}-0,116^{* * *} \\
(-0,020)\end{array}$ & $\begin{array}{c}-0,084^{* * *} \\
(-0,026)\end{array}$ & $\begin{array}{c}-0,116^{* * *} \\
(-0,017)\end{array}$ & $\begin{array}{c}-0,161^{* * *} \\
(-0,026)\end{array}$ & $\begin{array}{c}-0,049 \\
(-0,051)\end{array}$ & $\begin{array}{l}0,187 \\
(-0,878)\end{array}$ \\
\hline Post $02 / 05 / 2011$ or $3 / 10 / 2011$ & $\begin{array}{l}0,111^{* * *} \\
(-0,017)\end{array}$ & $\begin{array}{l}0,111^{* * *} \\
(-0,017)\end{array}$ & $\begin{array}{l}0,045 \\
(-0,030)\end{array}$ & $\begin{array}{l}0,044 \\
(-0,030)\end{array}$ & $\begin{array}{l}0,004 \\
(-0,049)\end{array}$ & $\begin{array}{l}0,004 \\
(-0,049)\end{array}$ \\
\hline Constant & $\begin{array}{l}4,252^{* * *} \\
(-0,013)\end{array}$ & $\begin{array}{l}4,252^{* * * *} \\
(-0,013)\end{array}$ & $\begin{array}{l}4,323^{* * * *} \\
(-0,024)\end{array}$ & $\begin{array}{l}4,335^{* * *} \\
(-0,025)\end{array}$ & $\begin{array}{l}4,334^{* * *} \\
(-0,035)\end{array}$ & $\begin{array}{l}4,334^{* * *} \\
(-0,035)\end{array}$ \\
\hline $\mathrm{R}^{2}$ & 0,244 & 0,25 & 0,38 & 0,386 & 0,08 & 0,081 \\
\hline $\mathrm{R}^{2}$ Adjusted & 0,239 & 0,243 & 0,362 & 0,366 & 0,04 & 0,027 \\
\hline Observation & 462 & 462 & 462 & 462 & 74 & 74 \\
\hline Tendency & No & Yes & No & Yes & No & Yes \\
\hline Seasonality & No & No & Yes & Yes & - & - \\
\hline
\end{tabular}


Table D.7: “Temporal Placebo" Efficiency

\begin{tabular}{|c|c|c|c|c|c|c|c|c|c|c|}
\hline & \multicolumn{4}{|c|}{$\begin{array}{c}\text { Full Sample } \\
(01 / 11 / 2010-30 / 10 / 2012)\end{array}$} & \multicolumn{4}{|c|}{$\begin{array}{c}\text { Six month sample } \\
(02 / 05 / 2011-30 / 04 / 2012)\end{array}$} & \multicolumn{2}{|c|}{$\begin{array}{c}\text { One month window } \\
(03 / 10 / 2011-30 / 11 / 2011\end{array}$} \\
\hline & coef/se & coef/se & coef/se & coef/se & coef/se & coef/se & coef/se & coef/se & coef/se & coef/se \\
\hline Monitoring effect & $\begin{array}{l}-0,031 \\
(-0,053)\end{array}$ & $\begin{array}{c}-0,053 \\
(-0,093)\end{array}$ & $\begin{array}{l}-0,031 \\
(-0,047)\end{array}$ & $\begin{array}{l}0,099 \\
(-0,090)\end{array}$ & $\begin{array}{l}0,085 \\
(-0,076)\end{array}$ & $\begin{array}{l}0,071 \\
(-0,124)\end{array}$ & $\begin{array}{l}0,084 \\
(-0,055)\end{array}$ & $\begin{array}{l}0,038 \\
(-0,110)\end{array}$ & $\begin{array}{l}0,008 \\
(-0,127)\end{array}$ & $\begin{array}{l}0,030 \\
(-0,157)\end{array}$ \\
\hline Group 2 & $\begin{array}{c}-0,039 \\
(-0,025)\end{array}$ & $\begin{array}{c}-0,050 \\
(-0,047)\end{array}$ & $\begin{array}{c}-0,039 \\
(-0,028)\end{array}$ & $\begin{array}{c}0,026 \\
(-0,049)\end{array}$ & $\begin{array}{l}-0,037 \\
(-0,030)\end{array}$ & $\begin{array}{c}-0,059 \\
(-0,118)\end{array}$ & $\begin{array}{c}-0,037 \\
(-0,030)\end{array}$ & $\begin{array}{c}-0,107 \\
(-0,129)\end{array}$ & $\begin{array}{c}-0,004 \\
(-0,067)\end{array}$ & $\begin{array}{c}0,264 \\
(-1,367)\end{array}$ \\
\hline Post $01 / 11 / 2011$ & $\begin{array}{c}-0,311^{* * *} \\
(-0,030)\end{array}$ & $\begin{array}{c}-0,311^{* * * *} \\
(-0,030)\end{array}$ & $\begin{array}{c}-0,313^{* * * *} \\
(-0,026)\end{array}$ & $\begin{array}{c}-0,313^{* * * *} \\
(-0,026)\end{array}$ & $\begin{array}{c}-0,400^{* * * *} \\
(-0,046)\end{array}$ & $\begin{array}{c}-0,400^{* * * *} \\
(-0,046)\end{array}$ & $\begin{array}{c}-0,173^{* * * *} \\
(-0,067)\end{array}$ & $\begin{array}{c}-0,213^{* * *} \\
(-0,073)\end{array}$ & $\begin{array}{c}-0,083 \\
(-0,081)\end{array}$ & $\begin{array}{c}-0,083 \\
(-0,082)\end{array}$ \\
\hline Constant & $\begin{array}{l}4,089^{* * * *} \\
(-0,015)\end{array}$ & $\begin{array}{l}4,089^{* * *} \\
(-0,015)\end{array}$ & $\begin{array}{l}4,243^{* * *} \\
(-0,037)\end{array}$ & $\begin{array}{l}4,219^{* * * *} \\
(-0,038)\end{array}$ & $\begin{array}{l}4,101^{* * * *} \\
(-0,017)\end{array}$ & $\begin{array}{l}4,101^{* * *} \\
(-0,017)\end{array}$ & $\begin{array}{l}4,055^{* * *} \\
(-0,036)\end{array}$ & $\begin{array}{l}4,101^{* * *} \\
(-0,038)\end{array}$ & $\begin{array}{l}4,095^{* * * *} \\
(-0,039)\end{array}$ & $\begin{array}{l}4,095^{* * * *} \\
(-0,039)\end{array}$ \\
\hline $\mathrm{R}^{2}$ & 0,146 & 0,146 & 0,339 & 0,341 & 0,165 & 0,165 & 0,567 & 0,567 & 0,024 & 0,024 \\
\hline $\mathrm{R}^{2}$ Adjusted & 0,143 & 0,142 & 0,329 & 0,33 & 0,16 & 0,158 & 0,554 & 0,553 & $-0,021$ & $-0,036$ \\
\hline Observations & 927 & 927 & 927 & 927 & 459 & 459 & 459 & 459 & 70 & 70 \\
\hline Tendency & No & Yes & No & Yes & No & Yes & No & Yes & No & Yes \\
\hline Seasonality & No & No & Yes & Yes & No & No & Yes & Yes & - & - \\
\hline
\end{tabular}

Note: ${ }^{* * *} p<0.01,{ }^{* *} p<0.05,{ }^{*} p<0.1$

Source: Own elaboration parting from the results. 